\title{
Die apologetiese taak van die kerk ${ }^{1}$
}

\author{
I W C van Wyk (AIM) \\ Hervormde Teologiese Kollege \\ Universiteit van Pretoria
}

\begin{abstract}
Apology as the church's responsibility

In 2001, the Nederduitsch Hervormde Church decided that apologetics should be part of its apostolate. The author introduces the subject of apologetics to the church. This he does by means of a historical overview of the development of the subject. Special attention is given to the early apologetic fathers and theologians of the $19^{\text {th }}$ and $20^{\text {th }}$ centuries. The emphasis falls on the problematic relationship between faith and science, questions concerning the truth of the gospel, the mission of the church and the problem of multi-religiosity.
\end{abstract}

\section{INLEIDING}

Die Nederduitsch Hervormde Kerk het met die aanvaarding van haar nuwe Kerkorde tydens die Buitengewone Algemene Kerkvergadering in 1997 gestel dat sy die taak het "om valse leerstellings te bestry". In Ordinansie 5.7.3 is gesê: "Die Kerk bestry alle wêreldbeskouings, filosofieë, ideologieë en dwaalleringe wat met die Woord van God, belydenisse en belydenisskrifte van die Kerk in stryd is, deur die evangelie in die wêreld te verkondig." Die opskrif van hierdie Ordinansie is egter, op die outeur se voordrag, in 2001 tydens die $66^{\mathrm{e}}$ Algemene Kerkvergadering verander. "Bestryding van leerstellings" is vervang met "Apologie". Met die verandering van hierdie opskrif kon die Kerk dus 'n nuwe koers inslaan vir haar apostolêre taak in die wêreld.

Daar was vir my drie goeie redes hoekom die opskrif moes verander:

- Die nuwe koers is deur ons omgewing genoodsaak:

Die gedagte van "bestryding" het teruggegaan op die posisie van mag van die Afrikaner in die vorige bedeling. "Apologie" dui op 'n posisie van beskeidenheid. In die huidige bedeling het ons nie die mag om na willekeur allerlei dinge te bestry nie, maar word ons gedwing om, in 'n

\footnotetext{
${ }^{1}$ Hierdie artikel is 'n verwerking van 'n lesing gehou op 6 Mei 2004 tydens 'n simposium van die Raad vir Apostolaat in Pretoria oor dieselfde tema.
} 


\section{Die apologetiese taak van die kerk}

situasie van godsdiensgelykheid en vyandigheid jeens die Afrikaanse kerke, in nederigheid op te kom vir wat ons glo.

- Die nuwe koers reflekteer die wil van die Kerk self:

Die Hervormde Kerk het oor die afgelope dekade, stadig en moeisaam tot die besef begin kom dat sy 'n roeping het om uit te reik na die wêreld en die omgewing rondom haar. Sy het tot die ontdekking begin kom dat gehoorsaamheid aan die apostolaatsopdrag nie 'n debatteerbare saak is nie. Haar na-binne-gekeerde selfgenoegsaamheid het 'n onbehaaglikheid begin word. 'n Apostolêre bewussyn beteken onder andere, dat sy op die aanklagte, verwyte en vrae van minstens haar eie kerkvervreemde lidmate sal moet begin reageer. Apologie het dus 'n dringende noodsaaklikheid geword.

- Die nuwe koers word deur 'n nuwe godsdienstige situasie genoodsaak: Ons nuwe Suid-Afrikaanse omgewing veroorsaak dat talle ou sekerhede aan die wankel begin raak het. Die nuwe vrye mark van godsdienstige en wêreldbeskoulike pluralisme het ons kwesbaarheid in terme van ons waarheidsaansprake begin blootlê. Ons onvermoë om met die "verhellenisering" van ons wêreld af te reken, noodsaak ons om (minstens) weer die werke van die vroeë apologete te bestudeer. "Apologie" vra dus om 'n koersaanpassing in ons teologie. Die bestudering van die Patristiek sal op hierdie stadium van ons lewens 'n waardevolle toevoeging tot ons teologiese nadenke wees.

Hierdie artikel, as 'n eerste inleidende en oorsigtelike bydrae tot die besinning oor die apologetiese taak van die Kerk, het ten doel om predikante en lidmate van die Kerk bekend te stel aan die betekenisvelde van die woorde "apologie" en "apologetiek" asook die groot variasie van apologetiese strategieë wat deur die loop van die eeue gevolg is. In die proses sal ons op drie teologiese vraagstukke konsentreer naamlik: Die verhouding tussen die Christelike geloof en die Westerse wetenskaplike wêreld, die vraag na die waarheid van die Christelike godsdiens en die probleem van godsdienstige pluralisme. Al drie hierdie vraagstukke is vir ons in hierdie land van uiterste belang. In die toekoms sal ons in afsonderlike studies na hierdie temas terugkeer.

\section{DIE OORSPRONGE VAN "APOLOGIE"}

'n Lastige probleem rakende "apologie" is dat talle mense nie bekend is met die betekenis van die woord nie. Verskillende mense hoor verskillende dinge in hierdie woord. Volgens sommiges, is die woord "apologie" nie 'n bruikbare term nie, aangesien dit klink of ons verskoning moet maak omdat ons glo. Ander het weer die gevoel dat "apologie" te make het met intellektuele 
geloofsintimidasie wat nie kan inpas in ons wêreld waar toleransie dogmatiese status verwerf het nie.

"Apologie" en "apologetiek" (die vakgebied wat met die apologie te make het) is verseker nie helder aangeleenthede nie. Ons moet dadelik toegee dat daar talle verskillende opinies en menings aangaande hierdie sake bestaan, en dat daar verskillende denkrigtings en skole bestaan wat hierdie sake probeer bevorder. In die volgende klompie paragrawe gaan ek inligting verskaf oor die verskillende betekenisvelde van hierdie woorde asook die verskillende skole van denke wat hieruit na vore getree het.

\subsection{Grieks-filosofiese agtergrond}

Die woord "apologie" het 'n Grieks-filosofiese agtergrond. Die Griekse woord apología het die aanvanklike betekenis gehad van iemand wat hom voor 'n geregshof moet regverdig deur sy onskuld te bewys. Die term (en hierdie spesifieke betekenis van die woord) het veral bekendheid verwerf deur Plato (427-347 vC) se geskrif die Apologie van Sokrates. In Plato se woorde verdedig Sokrates homself (in $399 \mathrm{vC}$ ) voor die gereg ('n jurie van 500 mense) op aanklagte van ongodsdienstigheid en korruptering van die jeug. In Plato se werk beteken die woord apologie dus ' $n$ verdedigingsrede teen bepaalde, onregverdige, aanklagte. Apo-logia (om weg te redeneer) is dus in die Platoniese betekenis van die woord, ' $n$ verduidelikende diskoers dat die aanklagte teen jou geen water hou nie (West 1979:51, 71).

Die woord is later deur die godsdienstige gemeenskap oorgeneem. Binne verskillende godsdienstige kontekste is die volgende betekenisveld daaraan gekoppel: Die selfregverdiging van 'n godsdienstige minderheid voor die gereg en gerig (letterlik en metafories) van die wêreldbeskoulik-dominante groep op allerlei aanklagte rakende hulle lewenshouding en geloof (Usarski 1998:611). Die woord "verdediging" het egter van meet af aan die volgende betekenisvelde ingesluit: Regverdiging, verduideliking en verheldering. Met hierdie stukkie inligting in gedagte, kan ons nou 'n paar treë verder gee op ons soektog na duidelikheid waaroor "apologie" nou eintlik handel.

\subsection{Apologie in die Bybel}

Die woord apologie en die gedagte van apologie aanteken kom mens ook in die Judaïsme en heelwat plekke in die Bybel teë. Aangesien hierdie 'n inleidende en oorsigtelike artikel is, word daar kortliks na net die volgende verwys:

\subsubsection{Apologie in die Jodedom}

Apologie as ' $n$ kritiese gesprekvoering met die eie religieuse omgewing het in die geskiedenis van die Joodse volk eers in die tydperk van die Hellenistiese diaspora op die voorgrond getree. 'n Belangrike rede was die ontstaan van 


\section{Die apologetiese taak van die kerk}

heidense anti-Joodse literatuur in plekke soos Alexandrië. Vanaf die derde eeu v C tot die eerste eeu $\mathrm{n} C$ het daar in die Hellenistiese Egipte byvoorbeeld weergawes van die Joodse Exodusverhaal verskyn wat Moses uitgebeeld het as 'n "kultuurvyandige barbaar" (Maneto, Chaeremon en Apion). Daar was ook nydige geskrifte wat die Joodse wette (die Sabbat as 'n voorbeeld van Joodse luiheid) en geloofsbelydenis (monoteïsme as ateïsme) met argwaan bejeën het. Hierdie geskrifte is later listig aangewend deur Romeinse filosowe soos Tacitus in polemiek teen Jode en Christene. Joodse apologete soos Artapanos (200 vC) het die taak aanvaar om byvoorbeeld verweerskrifte oor Moses en die Exodusverhaal te boek te stel. Moses is uitgebeeld as die vader van die moderne beskawing van daardie tyd (Amerikaanse apologete voer vandag dieselfde tipe argument - kyk na Moreland 1996 en Helseth 2000). Die argument is gevoer dat die Hellenisme ondenkbaar sou wees sonder die nalatenskap van Moses. Die groot Joodse godsdiensfilosoof, Aristobulus, het met behulp van die allegoriese metode (wat deur die Stoa ontwikkel is) aangetoon dat die Septuagint die grootste Hellenistiese literatuurprestasie was. Die grootste antieke Joodse apologete was Philo van Alexandrië en Flavius Josephus in die eerste eeu nC. Philo se Apologia pro ludaeis (wat verlore is) was 'n poging om die redelikheid van die Joodse wette aan te dui. Josephus se Contra Apionem was 'n poging om die verhewendheid en eerbiedwaardigheid van die Joodse kultuur (wat op Moses teruggaan) aan te dui (vgl Van der Horst 1998 vir die literatuur op hierdie gebied).

\subsubsection{Apologie in die Nuwe Testament}

'n Blik op die gebruik van die woord "apologie" in die Nuwe Testament (kyk o a na Reid 1970:15-35 vir meer inligting) gee aan 'n mens 'n goeie aanduiding van die betekenis- en gebruiksvelde van die woord. Soos wat hieronder gesien sal word, het hierdie aspekte telkens in die geskiedenis van die teologie weer en weer na vore getree. Die volgende paar aspekte kan hier genoem word:

- $\quad$ Christene teken apologie aan, of gee redes hoekom hulle hoopvolle mense is. 1 Petrus 3:15 sê: Wees altyd gereed om 'n antwoord te gee aan elkeen wat van julle 'n verduideliking eis oor die hoop wat in julle lewe.

- $\quad$ Om apologeties vir die evangelie in te tree beteken eintlik maar om belydenis van jou geloof te doen. Die volgende twee teksverse bevestig hierdie stelling: Matteus 10:32: Elkeen wat hom voor die mense openlik vir My uitspreek, vir hom sal Ek My ook openlik uitspreek voor my 
Vader wat in die hemel is. Handelinge 17:2-4: ... Hy het die Skrif uitgelê en daaruit aangetoon dat die Christus moes ly en uit die dood opstaan. 'Hierdie Jesus wat ek aan julle verkondig', het hy gesê, 'Hy is die Christus'.

- $\quad$ 'n Ander aspek van apologie aanteken kom neer op die verdediging van die geloof. In Handelinge 4:19-20 lees ons: Maar Petrus en Johannes het vir die Joodse Raad gesê: Julle moet maar self besluit wat voor God reg is: om aan julle gehoorsaam te wees of aan God. Wat ons betref, dit is onmoontlik om nie te praat oor wat ons gesien en gehoor het nie. So ook in Handelinge 22:1: Broers en vaders, luister na wat ek nou tot my verdediging vir julle wil sê.

- $\quad$ Om apologie aan te teken beteken verder om aan die openbare godsdienstige diskoers deel te neem. Hierdie deelname is 'n Christen se plig. Hierdie optrede kan egter ook groot lyding meebring soos ons lees in Handelinge 19:8-10 en 2 Timoteus 4:16-18.

- $\quad$ Apologie het van die begin af te doene gehad met dialoogvoering met ander godsdienste. Die gesprek rondom die waarheid van die Christendom was van die begin af in die sentrum van Paulus se gesprekke met mense uit die tradisionele Griekse en Romeinse godsdienste. Paulus se optrede op die Areopagus in Handelinge 17:2234 is die locus classicus: ... Ateners, ek sien dat julle in alle opsigte baie godsdienstige mense is ... Nou ja, wat julle aanbid sonder om daarvan kennis te hê, verkondig ek aan julle.

- Apologie is nie slegs die taak van prominente leiers in die kerk nie, maar die taak van elke lidmaat. Paulus vra byvoorbeeld in Filippense $1: 7$ en 17 dat almal hom moet help met die verdediging van die evangelie.

Konklusie: Ná 'n vinnige kykie na 'n paar teksverse kan ons nou die volgende gevolgtrekking maak:

- $\quad$ In 'n wêreld met 'n onsimpatieke owerheid en omring deur ander godsdienste, was gelowiges genoodsaak om die evangelie te verdedig teenoor die aanklagte, beskuldigings en bespottings van owerhede, ander godsdienstige groeperinge en die publiek.

- $\quad$ Apologie is nie net verdediging nie, maar ook die positiewe aflê van getuienis. 


\section{Die apologetiese taak van die kerk}

- $\quad$ In die eerste dekades van kerkwees, moes die gelowiges veral getuig oor die Vader van Jesus Christus as die ware God, Christus as die ware Heer, die opstanding van Christus en ons rede vir 'n bestaan in hoop.

\subsection{Die apologete}

Die eerste geslag Christene, volgens wat ons weet uit die oudste beskikbare literatuur, was nie bekommerd oor hulle groter Hellenistiese omgewing nie. Die Apostoliese Vaders (1 Clemens, Didache, Hermas, Ignatius van Antiochië, Polikarpus van Smirna, Barnabasbrief) het eerder geworstel met die vestiging van die geloof en die kerklike tug binne die eerste gemeentes. Hulle geskrifte het gekonsentreer op binne-kerklike probleme soos kerklike twiste (1 Clemens), Liturgie (Didache), die sonde van begeerlikheid (Polikarpus van Smirna).

Dinge het egter dramaties gedurende die $2^{\mathrm{e}}$ eeu verander - die tydperk van die Klassieke Apologete (kyk Tertullian 1984:11-51; Bergjan 2001 vir agtergrondsinligting). Die doelwitte van die Klassieke Apologete (onder andere Aristides, Quadratus, Justinus, Melito, Athenagoras, Tertullianus, Tatianus, Teofilus van Antiochië e a ) was die volgende:

- $\quad$ Om te bewys dat die Christendom 'n wettige en respektabele godsdiens is wat nie vervolging verdien nie. Christene is nie skuldig aan kriminaliteit nie en ondergrawe nie die staat nie. Hulle het daarom die uniekheid van die eie lewensvoering verdedig en verduidelik teen booswillige aanvalle en valse beskuldigings. Hulle apologie was om die Christelike lewensvoering te verdedig as die hoogste etiese ideaal.

- $\quad$ Om te bewys dat die Christendom 'n redelike godsdiens is - trouens die ware redelike godsdiens is en dat die Romeinse godsdienste die produk is van bose drifte en drange.

Om in hierdie doelwitte te slaag, moes hierdie apologete intens worstel met die verhouding tussen Christendom en die antieke kultuur en filosofie. Een van die sentrale vrae was: Wat is verlossing binne 'n kultuur van pluralisme? Verlossing was vir die apologete verlossing uit die kultuur van demone en sataniese drifte. Dit was verlossing uit die irrasionele tradisionele godsdienste en die deel in die absolute redelikheid van die Christelike godsdiens. Hierdie redelike godsdiens het vir hulle uiting gevind in die gebed tot en gehoorsaamheid aan die één God. In hierdie stryd het hulle 'n bondgenoot gevind in die antieke filosofie. Dit is daarom nie vreemd dat net Tatianus die totale Griekse 
kultuur, insluitend die filosofie verwerp het nie. Al die ander apologete het gesoek na 'n sintese tussen kerk en kultuur, teologie en filosofie (Barnard 1978, Skarsaune 1998:617).

Sommige van die Latere Apologete (3e-5e eeue) het verdere aandag aan die ou probleme geskenk, terwyl ander weer op ander vraagstukke gewerk het. Ek noem kortliks enkele voorbeelde: Eusebius het in sy Praeparatio evangelica die evangelie teen aanklagte van Celsus en Porphyrius verdedig. Hy het saam met die klassieke apologete die tradisionele volksgodsdienste verwerp, maar weer in teenstelling tot hulle die tese verdedig dat die Christelike oortuigings op suiwer geloof berus en geen rasionele argumente vir sy verdediging benodig nie. Hy het ook die taak gehad om die Romeinse owerhede te oortuig dat die Christendom nie polities en maatskaplik subversief is nie.

Origenes se Contra Celsum was die begin van 'n nuwe tipe apologie. Vir die eerste keer in die geskiedenis het dit nodig geword om die betroubaarheid van die Bybel as historiese bron te verdedig. Die apologie van die vroeë Protestantse Ortodoksie sou hierdie tema weer opneem en verder uitbou (ons keer later terug na hierdie saak).

Athanasius se werke Contra gentes en De incarnatione verbi wou Christus as ware verlosser verdedig. Hy het die oortuiging gehad dat só iets net moontlik sou wees met die uitwerk van 'n volledige Christologie. Die eerste Christologie was dus ten diepste 'n stuk apologie (Skarsaune 19989:616-620). Ek noem dit, aangesien ons sal sien dat hierdie tendens in die 20 e eeu terugkeer. Sekere teoloë soos Paul Tillich se dogmatiese geskrifte is deur en deur apologie

Samevatting: 'n Kykie (meer ruimte sou verwysings na talle ander apologete moontlik gemaak het. Kyk self na o a Logan 2001 en Paulsen 1977) na die vroeë Apologete bring ons tot die besef dat apologie minstens met die volgende te make het (Berkhof 1941:31-32; Bakhuizen 1965:78-83; Hauschild 1995:105-128; Geerlings 2002:7-12):

- Apologete verdedig die evangelie en die kerk teen valse beskuldigings.

- $\quad$ Apologete worstel intens met die verskynsel van godsdienstige pluralisme. Hulle voer redes aan hoekom die Christelike godsdiens "verhewe" sou wees bo die stam- of tradisionele godsdienste.

Ons maak egter nou 'n groot sprong na die ná-Reformatoriese tyd om aan die einde weer terug te keer na die Vroeë Apologete! 


\section{APOLOGIE EN APOLOGETIEK IN DIE MODERNE}

Die Reformasie het nie juis apologetiese geskrifte opgelewer nie, aangesien die Reformatore se lewenstaak toegespits was op die polemiek of die binnekerklike twisgesprek.

Behalwe vir enkele belangrike apologetiese geskrifte van die vroeë Ortodoksie (waarna ons kortliks sal terugkeer), was dit eers die godsdiensfilosowe van die $17 \mathrm{e}$ en $18 \mathrm{e}$ eeue wat weer belangrike apologetiese werke gelewer het. Ons kan kortliks verwys na Pascal (1623-1662) wat 'n reeks gelowige denkers gemotiveer het om saam met hom pogings aan te wend om die Christendom teenoor die Deïsme te verdedig. Die teodiseeprobleem het ook 'n belangrike rol in die apologie van die gelowige filosowe gespeel. Hier kan slegs gedink word aan die teodisee van Leibniz (1710).

Die teologie van die $19 \mathrm{e}$ eeu is vir ons tema van groot belang. Sonder kennis en begrip van die problematiek en stryd gedurende hierdie eeu, sal ons nie die noodsaak en problematiek van die apologie, sowel as die ontwikkeling en krisis van die apologetiek (die vakgebied van die apologie) verstaan nie.

Die teologie van die 19 e eeu was 'n worsteling met die konsekwensies van die Verligtingsfilosofie van die $17 \mathrm{e}$ en $18 \mathrm{e}$ eeue. Die Verligting was skepties teenoor die godsdiens. Hierdie filosofie het die godsdiens wel 'n plek binne die private eksistensie en die moraal gegun, maar nie binne die sfeer van die rede nie. Hierdie standpunt het geweldige bedreigings vir die kerk en die teologie ingehou; onder andere die verlies van 'n staanplek aan die universiteit. Die teoloë van die $18 \mathrm{e}$ en $19 \mathrm{e}$ eeue het op verskillende wyses en met verskillende invalshoeke op hierdie problematiek gereageer. Hierdie verskillende reaksies sou die fondamente lê vir die verskillende teologiese strominge wat tot vandag toe die teologiese toneel (ook binne ons Kerk) oorheers.

\subsection{Ortodoksie}

Die eerste reaksie wat genoem moet word, is die reaksie van die Ortodokse Christendom, aangesien die dogmatiese Christendom die hardste getref is (en word) deur die godsdiensvyandigheid en kerkvervreemding. Binne hierdie groepering bestaan daar dus 'n groot behoefte aan apologie of geloofsweer. Wat uniek is en was van die ortodokse apologete, is dat hulle nie net belang gestel het in 'n verdediging van die geloof nie, maar in die verdediging van die dogmas waarin die geloof verwoord is. Konfessioneel-Gereformeerde apologetiek was dus van die begin af toegespits op die verdediging van die Gereformeerde leer (of dogmas) teen aanvalle van veral die rasionalisme en positivisme. Een van die belangrike name wat in hierdie verband genoem kan word is die Amsterdamse teoloog V Hepp (1922). 
Apologie en apologetiek binne die konfessionele groepering kan egter nie beperk word tot die krampagtige verdediging van ou Calvinistiese leerstellings nie. Belydende Christene kan ook op totaal ander wyses apologie aanteken vir die geloof wat ons bely. Indien ons onder apologie die volgende verstaan: Intellektuele hulp om geloofshindernisse uit die weg te ruim en hulp tot die verstaan en innerlike aanneming van die geloof; dan sou ons ook die ontmitologiseringsdebat wat ná 1945 tot stand gekom het, as Protestantse apologetiek kon opneem (onthou Bultmann was 'n toegewyde Lutheraner vgl Neuenschwander 1975:99-128).

'n Ander interessante apologetiese verskynsel binne die konfessionele teologie van die laaste dekades is die ontstaan van gemeentelike gesprekke, voortgesette volwasse kategese en die volwasse kategismus (Evangelischer Erwachsenen Katechismus) in Duitsland. Die agtergrond van die "dialogiesegemeenteteologie" (Bybelstudie!) het 'n apologetiese agtergrond, in die lig van die feit dat gemeentelede versoeke het tot opheldering van die prediking, dat hulle kommentaar wil lewer en selfs kritiek wil uitspreek. Die bedoeling van hierdie Kategismus is (a) om ' $n$ handboek vir gemeentelike gespreksvoering aan te bied en (b) om die skepties-geworde na-oorlogse generasie ' $n$ hele lewens- en wêreld beskouing aan te bied as antwoord op die geloofsvyandige lewensfilosofieë van die $20 \mathrm{e}$ eeu. Een van hierdie lewensfilosofieë wat beveg word is die oortuiging dat slegs dinge wat "werkbaar" en praktiese voordeel het, waarde het. Die vervanging van "redelikheid" met "praxisbeheptheid" as die maatstaf vir die duldbaarheid van godsdiens, het die kerk in Duitsland dus genoodsaak om 'n apologie in die vorm van 'n kategismus te skryf (Jenssen 1971:802-803, Müller-Schwefe 1978:426).

\subsection{Geloof en wetenskap}

Dit het tradisie in Nederland geword om oor apologetiek te praat by afskeidsen intreeredes. Ek verwys na 'n paar voorbeelde: V Hepp praat in 1922 in Amsterdam oor "Gereformeerde Apologetiek". G Wisse praat in 1928 in Utrecht oor "Het apologetisch element in de bediening des Woords". J A Meijer praat in 1988 oor "Verantwoorde hoop - Christelijk Apologetiek in een hellenistiche wereld". K Veling het op 2 Junie 1995 in sy afskeidsrede as hoogleraar in die filosofie aan die Teologiese Universiteit van die Gereformeerde Kerken in Nederland te Kampen, gehandel oor die "Apologetisch motief". W H Velema het op 19 Januarie 1996, in sy afskeidsrede as hoogleraar aan die Teologiese Universiteit te Apeldoorn, gepraat oor "De taak van de apologetiek in de hedendaagse theologie" en Bram Van de Beek het op 21 September 2001 tydens sy intreerede as hoogleraar in die Simboliek aan die Vrije Universiteit te Amsterdam, apologie beoefen met sy rede "Ontmaskering: Christelijk geloof en cultuur". 


\section{Die apologetiese taak van die kerk}

Met die uitsondering van Van de Beek, het die meeste redes gehandel oor die problematiek van die redelikheid van die geloof en die teologie as wetenskap. Die rede vir hierdie toespitsing van die apologetiek lê in die bedreigde posisie van die teologiese fakulteite aan die universiteite in Nederland. Luide stemme klink al vir langer as 'n eeu in Nederland op dat teologie nie 'n wetenskap is nie, en daarom geen plek aan 'n universiteit verdien nie. Velema (1996:10-12) meen dat hierdie aanslag teen die kerk vergelyk kan word met die aanslag van Celsus in die $2 \mathrm{e}$ eeu. Hy meen dat dit vandag nie genoegsaam is dat die aparte vakke apologetiese momente na vore bring nie, maar dat daar 'n spesifieke vakgebied apologetiek moet wees wat hom voltyds aan hierdie saak kan wy.

Velema verwerp die gedagte van die apologie van die $18 \mathrm{e}$ eeu wat gepoog het om die Christelike geloof met rasionele argumente te verdedig. Hy (1996:14) volg die meer beskeie posisie van G van den Brink (1992) wat meen dat die apologetiek hom moet beperk tot die poging om die plousibiliteit van die Christelike geloof aan te dui binne die denkraamwerk van die kontemporêre sekulêre denke. Onder plousibiliteit verstaan Velema (1996:27) die beter redelikheid van die evangelie. Velema (1996:42-53) weet dat dit problematies is om die kruis te verdedig binne die dwaasheid van hierdie wêreld. Daarom beperk hy hom tot die opgawe om te wys dat dit nie onredelik en dwaas is om te glo nie. Die taak van die apologetiek is om te wys op die grense van die rede. Dit kan nie bewys dat die geloof rasioneel is nie, maar kan bewys dat die geloof nie irrasioneel is nie. Die metode wat hiervoor gevolg moet word is die metode van dialoog, van belangstelling in ander en die poging tot die verstaan van ander in 'n nie-aggressiewe wyse. Apologie moet vir ander kan bewys dat ons geloof bevredigend, sinvol en betekenisvol is. Dit moet getuienis aflê van die hoop wat in ons is. Apologie val daarom vir hom (en hiermee kan ek nie saamstem nie) binne die sfeer van die "preevangelisme" of die vooraf-werk van die sending wat ruimte wil maak vir die geloof. Maar heel insiggewend (en hiermee kan ek saamstem) meen hy dat die apologetiek deel moet vorm van die diakonologie, aangesien dít die beste wyse is om vandag die evangelie te kommunikeer.

Die filosoof Veling meen dat die (Christelike) filosofie ook 'n apologetiese taak het. Hy besef dat geloof 'n saak van die Heilige Gees is (Dordt 3 en 4, 11), maar meen ons moet gereed wees om rekenskap te gee van ons geloof. Rekenskap gee (apologie) beteken vir hom nie die verdediging van die geloof met behulp van rasionele argument nie. Filosofiese apologie kan volgens hom nie aangaan om bewyse vir die waarheid van die geloof te probeer lewer nie. Die rasionele argumente in die verlede ten gunste van die bestaan van God, het die bestaan van God juis in die Europese 
tradisie versluier. Aan die ander kant beweer hy dat dit egter net so gevaarlik en skadelik is om te beweer dat ons geen sinvolle argumente kan aanvoer ten gunste van ons geloof nie. Apologie beteken vir Veling die kritiese ontbloting van die waarheidsaansprake van die wetenskap en 'n aanval van die onsigbare dogmas van die gangbare wetenskap. Met hierdie benadering meen hy om die apologie van Pascal voort te dra. Pascal se apologie teenoor die wetenskap was dat die vermoë van die rede oorskat word. Pascal was oortuig dat daar genoeg rasionele argumente ten gunste van geloof opgenoem kan word, sonder dat mens probeer om die geloof met die rede te vervang. 'n Mens kan dus 'n "redelike teologie" bly beoefen, ten spyte daarvan dat mens weet dat geloof 'n saak van die hart is. Hy pleit dus daarvoor dat die filosofie deel van die kurrikulum sal bly, ten spyte daarvan dat die filosofie ons nie kan help om te glo nie (Veling 1995:5-17).

\subsection{Wetenskapsteorie}

Die posisie van die Christendom in die wêreld, bepaal die wyse van apologie van die kerk. In die moderne, ná-Verligtingswêreld bestaan daar nie meer 'n eenheid van boodskap en wêreldbeeld nie. Al die wetenskaplike ontdekkings het ons wêreld verander. In hierdie situasie voel talle dat apologetiek 'n wetenskaplike regverdiging van geloof moet wees (soos Harrison 1999). Om hierdie rede het die wetenskapsteoretiese bemoeienisse die plek ingeneem van die apologetiek.

Die grondlegger van die teologiese wetenskapsteorie is die apologeet Friedrich August Tholuck (1826-1877). Sy boek Die leer oor die sonde en die verlossing (1823) het gehandel oor die stryd tussen godsdiens en wetenskap in die lig van die evolusiegedagtes van Darwin. Groot name wat later ook apologie as wetenskapsteorie beoefen het, is Paul Tillich, Wolfhart Pannenberg en Gerhard Sauter. Wat hierdie uiteenlopende mense met mekaar in gemeen het, is 'n poging om die evangelie voor die wetenskaplike rede te verdedig. Almal het 'n probleem met die totaliteitsaanspraak van die wetenskap, wat daarom nie aan die geloof ruimte gun as 'n dimensie naas die wetenskaplike rasionliteit nie (Beißer 1969:213-221).

\subsection{Die uniekheid van die geloof: Schleiermacher en sy Wirkungsgeschichte}

Friedrich Schleiermacher, een van die heel belangrikste apologete van die Christendom, het 'n totaal ander koers aangedui as reaksie op die Verligtingsproses. Dit is veral sy volgende twee geskrifte wat die hele koers, aard en tematiek van die teologie sou verander: (a) Sy boek Über die Religion: Reden an die Gebildeten unter ihren Verächtern (1799) wat gerig was aan die 


\section{Die apologetiese taak van die kerk}

geleerdes uit die kringe van die Romantiek, en (b) die hele inleidende gedeelte van sy Glaubenslehre (1821) wat aan alle veragters van die geloof gerig was.

Schleiermacher het as godsdiensfilosoof (en ons kom terug na hierdie saak) nie probeer om die Christelike geloof as redelik te regverdig nie, aangesien geloof vir hom nie met die rede te maak het nie, maar met die gevoel. Die gevoel van absolute afhanklikheid van God was vir hom ook nie 'n morele aangeleentheid nie. Hy het dus 'n pleidooi gelewer dat die geleerdes en skeptici ruimte moes laat vir godsdiens wat iets anders is as rasionaliteit en etiese plig (vgl Meuleman 1973:177).

Schleiermacher se apologie gaan egter om veel meer as 'n blote apologie vir geloof as gevoel. Dit was 'n nuwe wyse van omgang met die waarheidsvraag. Schleiermacher was oortuig dat die waarheidsvraag nie van absolute belang is vir die vooruitgang van die Christelike godsdiens nie. Volgens hom is dit nie nodig om te probeer bewys dat die evangelie ook op waarheid kan aanspraak maak nie. Dit is volgens hom genoeg as gelowiges sekerheid in hulle self het oor hulle eie vroomheid.

Agter hierdie omgang met die waarheidsvraag lê daar natuurlik iets anders van wesenlike belang. Die feit dat Schleiermacher nie begaan was oor die waarheidsvraag nie, en daarom nie geïnteresseerd was, byvoorbeeld in argumente oor die waarheid van die Skrif en die tradisionele dogmas nie, beteken nie dat hy nie wou opkom vir die evangelie nie. Hy was oortuig dat daar ' $n$ beter weg is om te volg - die weg van die hermeneutiek. Los die pogings om insig in die waarheid van die evangelie, en probeer eerder om die werklikheid te verstaan vanuit die perspektief van die geloof, was sy raad ( $\mathrm{vgl}$ Meuleman 1973:180).

Die apologie van Schleiermacher sou die beginpunt wees vir verskillende denkskole in die teologie gedurende die $20 \mathrm{e}$ eeu.

\subsubsection{Karl Barth: Die geloof alleen (sonder rasionele verdediging)} Volgens Karl Barth (KD II/1, 102; IV/3, 121) is die behoefte aan verdediging en verduideliking van die vooronderstellings, grense, sin en grond van ons belydenisse onbestrede. Wat egter wel omstrede is, is die metodes en kriteria van die apologetiek. Barth het gemeen dat apologetiek die programmatiese poging is om te bewys dat die stellings wat die teologie op grond van die openbaring aanvaar, in ooreenstemming is met die prinsiepes van die filosofie en van die natuur- en geskiedeniswetenskap (KD 1/1, 130, Meuleman 1973:152). In die lig hiervan kon hy nie positiewe aanklank vind by die apologetiek van sy dag nie aangesien hy (soos sy mentor Kierkegaard) nie geglo het dat ' $n$ rasionele verdediging van die geloof moontlik is nie. 'n Mens kan volgens Barth slegs geloofsredes aangee vir geloof. In hierdie sin was Barth dus 'n kleinkind van Schleiermacher. 


\subsubsection{Hermeneutiek en "Fundamentaltheologie"}

Schleiermacher se apologetiek was, soos ek reeds gesê het, die grondlegging van die teologiese hermeneutiek. Die vroeë Heinrich Ott (Barth se opvolger in Basel) is een van die bekende name wat hierdie aspek van Schleiermacher se apologetiek verder uitgebou het. Vir Ott is hermeneutiek die apologie van die 20e eeu. Apologie is die poging om die geloof met die sekulêre wêreld op só 'n wyse te kommunikeer dat dit verstaan sou kon word. Die teologiese taak van die $20 \mathrm{e}$ eeu is daarom nie om die waarheid van die evangelie teen dwaalleer te beskerm nie, maar om die evangelie verstaanbaar te maak vir mense wat nie meer kan glo nie. Hermeneutiek is dus die poging om te verduidelik waarop die geloof werklik aankom. Dit is 'n poging om rekenskap te gee oor my geloof en oor my verstaan van geloof. Hermeneutiek het die taak om die saak van die teks só uit te lê dat ongelowiges die boodskap nuut kan hoor. Dít, sê Ott, kan ek net doen as God vir my persoonlik iets beteken. Hermeneutiek is dus daardie aspek van teologie waar teksverstaan, saakverstaan en wêreldverstaan as 'n eenheid in die geloof byeen kom (Ott 1967:193-194).

Die latere Ott (1994) verkies egter om apologetiek Fundamentaltheologie ${ }^{2}$ te noem. Hierdie ekumeniese welwillendheid gaan terug op die woorde van Pous Johannes XXIII op 11 Okt 1962 tydens die opening van die Tweede Vatikaanse Konsilie toe hy gesê het: "Dit is nie nou die tyd om ander se leer te veroordeel nie, maar om ons eie leer te verduidelik" in terme van Fundamentaltheologie. Ott ondersteun die pous en sê dat die taak om te verduidelik en te verklaar juis in hierdie tyd van bindingslose pluralisme die aangewese weg is. Ons taak is volgens hom die ireniese, die niekonfrontatiewe by-die-saak-bly. Ons taak in hierdie tyd is nie die vreesbevange verdediging van die evangelie nie, maar die rustige verduideliking van ons saak. Op hierdie wyse sal apologetiek 'n vreugdevolle en hoopvolle saak bly.

Fundamentaltheologie, as die basis van alle regte teologie, leer ons dat die wese van die teologie daarop neerkom dat ons almal (in die verskillende vakgebiede) rekenskap moet gee van die hoop wat in ons lewe. Nie net apologetiek nie, maar teologie in die algemeen, behoort daarom rekenskapsleer te wees (en nie verdedigingsleer nie).

Ott meen dat die taak van die apologetiek in sy post-Christelike Switserland in die eerste instansie nie eers hoef te gaan om die verduideliking van die Christelike geloof nie, maar van die geloof in die algemeen. In dialoog,

\footnotetext{
${ }^{2}$ Fundamentaltheologie is ' $n$ bekende vakgebied binne die Rooms Katolieke kurrikulum - kyk byvoorbeeld na Fries 1985 - terwyl dit redelik onbekend is aan Protestantse fakulteite.
} 


\section{Die apologetiese taak van die kerk}

met die nie-meer-gelowige, moet ons verduidelik hoekom ons nog glo. Dít is die taak van die apologie in die Westerse wêreld vandag (Ott 1994:2-8).

Ott het verskeie bondgenote in hierdie onderneming soos Gerhard Ebeling en W Pannenberg. Ek wil (weens 'n gebrek aan ruimte) net één kort verwysing na een van die moderne apologete maak, naamlik Herman Kuitert. Kuitert meen dat in Holland die apologie nie eers meer gerig moet wees op die twyfelaars buite die kerk nie, maar op die twyfelaars binne die kerk. Vir hom moet apologie ' $n$ apologie van die godsdiens wees, aangesien lidmate [sic!] nie meer in 'n persoonlike God kan glo nie (Velema 1996:23).

\subsubsection{Die waarheidsvraag}

Ek het hierbo gestel dat Schleiermacher (1993:13-30) se apologie tuishoort in die godsdiensfilosofie. Hierdie is nie 'n niksseggende opmerking nie. Ons het 'n hele stuk teologiegeskiedenis te vertel oor hierdie saak.

Volgens Ebeling (1970:489) kom ons eers teen die einde van die 18e eeu 'n vak genaamd "Apologetiek" teë. In die ensiklopediese werk van G J Planck van 1794 genaamd Einleitung in die theologischen Wissenschaften lees ons vir die eerste maal dat daar so 'n vakgebied aan 'n universiteit ingestel is. Hierdie vakgebied, was merkwaardig genoeg, deel van die vakgroep "eksegese". Die gedagte was dat eksegese 'n apologetiese verantwoordelikheid sou opneem. Die eksegese van daardie tyd was nie veronderstel om hom te beperk tot historiese eksegese nie, maar moes die werk só doen dat die outoriteit en waarheid van die Skrif aan die lig sou tree. Hierdie eenheid van tekseksegese en saakeksegese het die noodsaak opgeroep dat 'n gesprek begin moes word oor die "waarheid van die Christendom". Marsilio Ficino en Ludwig Vives het die leiding in hierdie debat geneem (Pannenberg 1973:416).

Schleiermacher breek die verbinding tussen eksegese en apologetiek en maak dit deel van die godsdiensfilosofie. Met watter bedoeling? Met die bedoeling om van die vraag na die waarheid van die Christelike godsdiens ontslae te raak. Schleiermacher was oortuig dat 'n "bewys" van die waarheid van die Christendom nie die saak van die evangelie sou dien nie. Hy het gemeen dat konsentrasie op die uniekheid of besondersheid (Eigentümlichkeit) van die Christendom 'n beter diens aan die kerk sou lewer. Die vraag na die waarheid van die Christendom was vir Schleiermacher nie 'n saak van prioriteit nie, aangesien hy daarvan oortuig was dat geloof 'n saak van slegs persoonlike sekerheid is (Pannenberg 1973:416).

Ten spyte van die groot invloed van Schleiermacher betree H Sack in 1819 die eerste leerstoel vir apologetiek in Bonn met die opdrag om die geloofsubjektivisme te beveg en die waarheid van die Christendom te boek te 
stel. Vir die laaste twee eeue lank het die kerk besef dat die lot van die Christelike geloof nie aan die willekeur van die individuele gemoed oorgelaat kan word nie, maar dat die universele waarheid van die Christelike geloof argumentatief uitgewerk moet word. Een gestalte van hierdie poging is danksy prof Piet van der Merwe ook aan ons bekend, naamlik die "Teologie van die Godsdienste". Hierdie vakgebied word selfs aan sekere Europese fakulteite as die gronddissipline van die hele teologie gesien. Aangesien dit in hierdie vakgebied om die grondlegging van die teologie gaan, het dít ook bygedra tot die uitbou van die Fundamentaltheologie aan die Protestantse fakulteite. Vir die Fundamentaltheologie is die waarheid van die Christelike geloof die vertrekpunt van die Christelike teologie. Hierdie fokus was van groot belang vir die opkoms van die moderne sendingwetenskap.

Slotopmerkings: In die ekumeniese wêreld bestaan daar verskillende houdings oor die apologetiese taak van die kerk:

- Die Ortodokse Kerke stel nie belang in eietydse apologie nie. Hulle glo nie dat pogings om die geloof met rasionele argumente te probeer verdedig, enige waarde het nie. Om hierdie rede het die Russiese Ortodokse Kerk ook nooit amptelik met die Marxisme in 'n apologetiese dialoog betrokke geraak nie. Die Ortodokse Kerk konsentreer nie op die praktiese gebruik van die geloof nie, maar op die liturgie wat in die martelaarskap gegrond is.

- Vir die Rooms Katolieke Kerk is die Fundamentaltheologie (as 'n gestalte van apologetiek) weer 'n baie belangrike saak. Dit is trouens te wagte dat die Roomse Kerk baie positief oor hierdie aangeleentheid sal wees, aangesien hulle teologie gebou is op die oortuiging dat daar ' $n$ geprestabiliseerde harmonie tussen geloof en rede, openbaring en natuur bestaan.

- Die Westerse Protestantisme het 'n ambivalente houding jeens die apologie (en veral die apologetiek). Aan die een kant wys mense soos Bonhoeffer en Velema daarop, dat om te swyg die beste vorm van apologie is. Aan die ander kant wys mense soos Moltmann daarop dat geloof ' $n$ element van wêreld-gestaltegewing is. Om hierdie rede móét ons bou en ontwikkel, dialoog voer en kritiseer, ontbloot en onthul. En dít alles, is deel van die missionêre taak van die kerk (Müller-Schwefe 1968:426-429). 


\section{Die apologetiese taak van die kerk}

\section{MISSIONAAT EN APOLOGIE}

Apologie, die waarheidsvraag en sending is van vroeg af in die Protestantse tradisie (en selfs in die Russiese tradisie - Berdiajew 1930) as 'n eenheid behandel (Jongeneel 1999). Philippe Duplessis-Mornay (1549-1623) skryf alreeds in 1579 'n boek genaamd De veritate religionis christianae. In hierdie boek beveg hy die Epikureërs, Jode, Mohammedane en die ongelowiges. Hy probeer die "absoluutheid" van die Christendom te bewys deur te wys op die verhewe redelikheid van die Christelike godsdiens (sonder om die gedagte van die openbaring prys te gee). In 1627 skryf Hugo Grotius verskillende pamflette om die Hollandse seevaarders te help by hulle ontmoetings met mense van ander godsdienste (veral die Islam). Hy konsentreer op die opstanding van Jesus uit die dood, die lewe na die dood en die wonders van Jesus (Hepp 1922:17). Later sou niemand anders as Schleiermacher 'n pleidooi ten gunste van die apologetiek lewer, met die argument dat 'n kerk wat nie sendingkerk (en daarom nie apologie beoefen nie) is nie, nie kerk van Christus is nie (Meuleman 1973:180).

In 1921 is die Apologetische Centrale (Berlyn) deur die bestuur van die Innere Mission van die Duitse Evangeliese Kerk in die lewe geroep. Die taak van hierdie instituut was nie net die verdediging van die geloof nie, maar ook rigtinggewing in politieke en maatskaplike sake. In 1937 word hierdie instituut egter deur die Nazies gesluit, aangesien hulle veral by monde van die destydse leier, Walter Künneth, kritiek uitgespreek het teen die mite van die Derde Ryk. Danksy die teologiese invloed van mense soos Tillich en Brunner is die werk van hierdie instituut in 1960 in Stuttgart hervat onder die naam Die Evangelische Zentralstelle für Weltanschauungsfragen (Bolewski 1986, Slenczka 1995:13-15).

Die apologie en die apologetiek het sedert die veertiger jare van die $20 \mathrm{e}$ eeu ' $\mathrm{n}$ opbloei belewe aangesien die missiologie konjunktuur belewe het. Die groot ywer wat vir die sending ontstaan het, het die apologetiek tot in die hart van die teologie gebring. Die opbloei van die sendingwetenskap en die apologetiek het teoloë laat besef dat teologie as 'n selfgesprek nie veel sin het nie. Alle teologie behoort rekenskap te gee van ons geloof - en nie net die Apologetiek en die Fundamentaltheologie nie (Doerne 1950:262-264). Die dogmatiekhandboek van Th Haitjema (1948) Dogmatiek als Apologie: 'lk geloof in den God van Jezus Christus en die prakties-teologiese handboekies van Roscam Abbing (1954a en 1954b), wat die meeste ouer predikante op hulle boekrakke het (of gehad het)is 'n goeie voorbeeld van die pogings in daardie tyd. Haitjema het gesê dat dogmatiek apologetiek behoort te wees en dat apologetiek 'n missionêre saak is. Selfs die dogmatiek moet help om die evangelie uit te dra na die vyandige wêreld. Dogmatiek as apologie het die 
taak van die daarstelling van die geloof in die lig van die kritiek en bedenkings van die sekulêre wêreld. Dogmatiek moet dus eristiese teologie wees wat die kuns van disputering bemeester het. Dit moet dus eerder probeer om te oortuig as om te onderrig (Haitjema 1948:2-7).

Emil Brunner was 'n ander bekende dogmatikus wat dogmatiek vanuit 'n apologetiese of eristiese perspektief beoefen het (kyk vir volledigheid na Schrotenboer 1955). Volgens hom moet dogmatiek die kritiese gesprek van die kerk met die vyandige filosofieë en teologieë van die eie tyd wees (sonder om hulle van boosheid te beskuldig soos die "elenctiek" van Bavinck (1954) dit wil hê). Dogmatiek, moet net soos die apologetiek, die evangelie verdedig teen die aanklagte van rede-loosheid, kultuurvyandigheid, onwetenskaplikheid en onhoudbaarheid. Soos Pascal en Kierkegaard moet die dogmatiek nie net konsentreer op die ontbloting van die waarheid nie, maar ook op die oopvlek van die onwaarheid - en dít alles ten behoewe van net één saak, naamlik die sending van die kerk in die wêreld (Brunner 1929, 1960:105-109).

Sending en apologie het net sin as dit uiteindelik om geloof (geloof in die regverdig-makende God) en bekering gaan. Martin Kähler was die dogmatikus wat al hierdie aspekte byeen gebring het. In sy FundamentalDogmatik (wat hy as apologetiek verstaan het), het dit vir hom om die "ware Godsontmoeting" (nie net die ware godsdiens nie) gegaan. 'n Ware Godsontmoeting was vir hom slegs moontlik binne die gebeure van die regverdiging. Die apologetiek se taak is om die grond voor te berei vir hierdie boodskap. Dit moet die behoefte aan hierdie boodskap kan verduidelik. Metodies moet die apologetiese dogmatikus aanval en verweer. Dit moet die wêreld van die geloof aan skeptiese mense kan verduidelik sodat die vreemdheid van die geloof ' $n$ aanneemlike saak kan word. Apologie moet uiteindelik net die hoor van die Woord moontlik maak, sodat mense kan besluit wat hulle daarmee wil maak (Adam 1931:39-123).

Indien mens die apologetiese benadering van Kähler, Haitjema en Brunner bevredigend vind, kan dit gepas wees om Jenssen (1971:804-807) se raad te volg en apologetiek "intellektuele diakonie" te noem. Apologetiek as "diakonie van die denke" is eristiek wat in diens staan van die verkondiging, en wat die hoorder van die evangelie wil help deur positiewe en negatiewe polemiek om die waarheid van die evangelie te hoor. "Intellektuele diakonie" soek na aanknopingspunte in mense se denke en taalgebruik om die evangelie bloot te lê (Tillich), en dit het niks te make met menslike Rechthaberei soos die ou Godsbewyse nie. Dit is 'n hulpmiddel vir die verkondiging wat die werklikheid op só 'n wyse analiseer en ontbloot dat ruimte geskep word vir die regverdigingsboodskap. Sonder hierdie intellektuele dimensie, kan die evangelie maklik onder verdenking kom. 


\section{Die apologetiese taak van die kerk}

Ons sê dat apologetiek intellektuele diepte wil verleen aan die sending sodat die geloof nie net in die harte van mense sal lewe nie, maar ook in hulle koppe. Dit wil dus poog om 'n intellektuele klimaat te skep wat gunstig sal wees vir die ontstaan van geloof. A McGrath (1996:9-14) wys egter tereg daarop dat apologetiek in die verlede 'n saak van die akademiese klaskamer was aangesien die godsdienstige debat dáár beslis is. Vandag is dit egter 'n saak van die gemeenskap. Die godsdienstige debat word vandag beslis op $T$ $\mathrm{V}$, in die pers en in die werkplek. Die groot vrae is vandag: Is daar 'n God? Watse relevansie het die Christelike geloof vir my lewe en hoekom moet my lewe deur die Christelike geloof alleen bepaal word? Apologetiek sal hom dus moet bevry uit sy universitêre isolasie en die gemeenskap en sy probleme moet begin dien. Apologetiek sal dus nie net die saak van die universiteitsdosent kan bly nie, aangesien die ampsdraers en lidmate hulle redes vir hoop met die mense om hulle sal moet begin deel.

\subsection{Apologie, sending en die Christus belydenis in 'n pluralistiese wêreld}

Die probleem met ons teologie is dat dit eensydig aandag gee aan die voorpluralistiese wêreld van die Moderne. Waar daar wel aandag gegee word aan die sogenaamde postmoderne wêreld, word dit egter gedoen met 'n verlies aan teologiese integriteit. Wat kortsigtig misgekyk word, is dat ons wêreld, as die wêreld van wetenskap, tegnologie en vooruitgangsgeloof, ook gekenmerk word deur die terugkeer na die tradisionele, primitiewe, mitiese, voor-Aristoteliese denk- en lewenswyses. R Slenczka (1995:28-32) het dit raakgesien dat hulle in Duitsland nie meer uitsluitlik kan voorttokkel op die note van die moderne en sy dogmas (vooruitgangsgeloof, wetenskap as geloofsmag, politieke Messianisme) nie. Hulle behoort vandag te worstel met die gelyktydigheid van optimisme en apokaliptiese vrese, vertroue in die wetenskap en 'n wegvlug van die moderne lewe, die vashou aan die tradisionele geloof en die bekoring van lewenswyses wat niks met Bybel te make kan hê nie.

By ons is dit alles nog meer gekompliseerd. Ons leef in 'n land waar tradisionele godsdienstige en kulturele moraliteit 'n magtige invloed oor mense uitoefen. Tog verwag die staat en openbare media in hierdie land van ons om alle "Westerse" nuwighede te duld en alle bedenklike morele ontwikkelinge maar as goed en reg te aanvaar. Energieryke pogings is in hierdie land aan die gang om ons te probeer oortuig dat ons wêreld 'n "postmoderne wêreld" is. Dit mag gedeeltelik waar wees, maar hierdie is ook 'n wêreld waar die fundamentalisme en tradisionele godsdienstigheid steeds hoogty vier. Wat verder misgekyk word is dat "postmoderniteit" nie slegs 'n 
wegbeweeg, of erger nog, 'n verder-beweeg vanaf die tradisionele en behoudende is nie, maar dat dit ook 'n voortdurende terugkeer is na die primitiewe - ja, ook primitiewe godsdienstigheid. Ons leef dus in 'n radikaal pluralistiese wêreld. Afgesien daarvan dat ons in 'n land lewe met 'n groot verskeidenheid van rasse, kulture, tradisies en godsdienste - word hierdie land ook gekenmerk deur groeperinge wat min homogeniteit openbaar. In hierdie opsig is ons terug by die probleme van die eerste geslagte van Christene. Ons het nou ook (so die meeste Christene elders - Heim 1997) 'n "Hellenistiese wêreld" met sy pluralisme as uitdaging voor ons. Ons belydenis sal binne hierdie konteks verstaan, uitgelê en verdedig moet word.

Ons, as mense wat maar sopas bewus geword het van ons pluralistiese wêreld, kan gerus luister na 'n Afrikaan se raad ten opsigte van multigodsdienstigheid. Kwame Bediako (1996:27-40) van Ghana wys daarop dat Afrika 'n multi-godsdienstige kontinent is. In die lande waar die Christendom as die dominante godsdiens beskou word, het die invloed van die Tradisionele Afrika Godsdienste (TAG) nie afgeneem of verdwyn nie. Die unieke van Afrikane is dat hulle die vermoë ontwikkel het om beide godsdienste in hulle persoon te integreer - met ander woorde om sinkretisties te eksisteer. Daar bestaan dus nie 'n moontlikheid dat die Christus-belydenis in Afrika kan neerkom op 'n distansiëring of verwerping van die TAG nie. lemand sal byvoorbeeld bely "Christus is die Seun van God", maar tegelykertyd bely "my voorvader is ook seun van God". Die vraag in Afrika is dus: Hoe bely ons Christus as die Heer, as ons weet dat daar 'n alternatief lê en wag? Bediako meen dat ons raad kan kry by die vroeë Apologete uit Afrika soos Tatianus, Tertullianus en Justinus. Hierdie Afrika apologete het die Christus-belydenis wel as ' $n$ affirmatiewe uitspraak verstaan, maar hierdie affirmasie as erkenning en herkenning en nie as assertasie verstaan nie. Die belydenis moet dus stel hoekom Christus méér erkenning kry as die ander gode en voorvaders. My belydenis moet dus sê hoekom Christus 'n groot rol in my lewe speel en hoekom ek my vertroue op Hom kan stel. My belydenis is dus 'n stuk apologie vir Christus. Dit sê wie en wat Christus vir my is. Dit is dus geen abstrakte stellige bewering nie, maar ' $n$ eksistensiële bevestiging dat Christus ' $n$ belangrike rol in my lewe speel. Apologie in Afrika moet uitwys hoe Christus die antwoord kan wees op die vrae en soeke van die tradisionele mense. Dit moet daarop wys dat God in Christus die sterkere, magtiger Een is op wie jy kan vertrou. Die huidige Afrika, het net soos die Afrika in die tyd van die apologete, dus 'n groter behoefte aan monolatrie as aan monoteïsme. Apologie het dus nie die taak om die TAG te verkleineer nie, maar om die beter alternatief aan te bied (Bediako 1996:30-40). 
Hierdie artikel van Bediako is rede genoeg vir ons om ook terug te keer na die Vroeë Apologete om te gaan kyk wat ons verder by hulle kan leer oor die waarheid van die Christendom in 'n pluralistiese wêreld.

\subsection{Die Vroeë Apologete en die waarheidsaanspraak binne die pluralisme}

Een van die uitstaande verdienstes van die Vroeë Apologete was hulle intense kritiese debat met die godsdienstige pluralisme van hulle omgewing. Dit sal ons loon om hulle oortuigings en argumente op te diep as hulp vir die stryd wat nou voor ons lê. Ek steun op die magistrale werk van Fiedrowicz (2004:607-632) vir my inligting. Fiedrowicz verdeel die bydrae van die apologete in twee hooftemas, naamlik (a) die stryd met die pluralisme en sinkretisme en (b) die absoluutheidsaanspraak van die Christendom. Ek volg hom in sy indeling.

\subsubsection{Die stryd met die pluralisme en sinkretisme}

\subsubsection{Die verwerping van ander godsdienste as heilsweë}

Die apologete het, op grond van die Bybelse openbaring, die gedagte verwerp dat die Christendom 'n heilsweg naas andere kan wees. Hulle het twee argumente gevoer: a) Hulle het met beslistheid die geloof van die Grieke en die Egiptenare verwerp dat Zeus en Ammon Gode sou wees. Vir hierdie oortuiging was hulle selfs bereid om te ly. Dit was veral Origenes (Contra Celsum 5:46) wat met groot emosie teen die geloof in 'n panteon van gode te velde getrek het. b) Clemens van Alexandrie (Stromateis 1, 29, 1; 38, 6-7) het wel toegegee dat God op ander wyses redding kon bring, maar dat hierdie argument sy geldigheid verloor het, aangesien God in Christus nou dít waarna almal gesoek het, beskikbaar gemaak het aan alle mense.

Die apologete het op grond van Exodus 20:3.5 en Deuteronomium 4:25 die eis van monolatrie streng gerespekteer. Hulle verweer teen die spottende vraag hoekom die God van die Bybel dan nie ander gelowe en godsdienste verhinder en of beëindig nie, is deur Julianus (Contra Galilaeos 30) met 'n tweeledige antwoord begroet. Hy het gemeen dat die aanklag dat God nie in staat is om ander godsdienste te stop nie, godslastering en pure ongeloof is. Dat God nie ander godsdienste wil stop nie, is vir hom 'n sinnelose geklets, aangesien God se openbaring in Christus alles vertel oor die wil van God. Augustinus (Epistula 104,12-13) het 'n laaste belangrike argument in hierdie verband gevoer. Hy het gestel dat ander godsdienste slegs 'n eindelose strewe na verlossing is, sonder dat hulle die verlangde verlossing ooit werklik aan die volgelinge kan bied. Slegs die Christendom is waarlik 'n heilsweg, aangesien verlossing slegs via Jesus Christus 'n werklikheid is. 


\subsubsection{Verwerping van die sinkretistiese henoteïsme}

Sedert die tweede eeu $\mathrm{nC}$ was daar binne religieus-filosofiese kringe gewerk met die konsep van "sinkretistiese henoteïsme". Die idee van 'n hoogste God is aanvaar, maar hierdie God het elemente van die ander regionale gode vertoon. "God" is dus binne hierdie kringe 'n sinkretistiese samestelling van eienskappe versamel uit die regionale gode van die omgewing. Die apologete was oortuig dat hierdie godsbegrip in stryd was met die eerste gebod wat geen ruimte laat vir sinkretisme en pluralisme in die godsbegrip nie. Julianus (Contra Galilaeos 28) het byvoorbeeld daarop gewys dat Moses se verstaan van God onmoontlik versoenbaar kan wees met hierdie filosofiese godsbegrip.

\subsubsection{Die verwerping van die kennisteoreties-begronde relativisme} Die Griekse denker Xenophanes het alreeds in die sesde eeu vC aangevoer dat mense geen sekere kennis oor God en die gode kan hê nie. Hierdie skeptisisme oor enige religieuse dogmatisme het die belydenis van die Christene ten diepste geraak. Die apologete het die Christelike geloof passievol verdedig teen die religieuse relativisme van die Griekse filosowe. Op grond van die eerste gebod en die Christus-openbaring het hulle die mening verdedig dat Christene wel absolute godsdienstige kennis oor God kan hê (vgl Fiedrowicz 2004:617-620).

\subsubsection{Die Christelike absoluutheidsaanspraak}

Die Vroeë Kerk het voor die keuse gestaan om in die lig van die staatlik gesteunde godsdienstige pluralisme en relativisme, ter wille van persoonlike veiligheid, deel te word van die panteon godsdienste. Die implikasie sou wees dat die Christendom haar sou verlaag tot ' $n$ godsdiens naas ander godsdienste. Op grond van God se openbaring in Jesus Christus het hulle hierdie versoeking van selfrelativering weerstaan. Hulle was ook bereid om die bittere konsekwensies van hierdie beslissing te dra. Die volgende argumente was vir hulle van groot belang:

\subsubsection{Die verdediging van die absoluutheid van die Christendom op grond van die openbaringsgebeure}

Justinus (Apologia 23, 1-2) het teenoor die Griekse skrywers aangevoer dat die kennis aangaande Christus ware godsdienstige kennis is. Die rede wat hy aanvoer is dat die profetiese getuienis aangaande Christus baie ouer is as die Griekse godsdienstige geskrifte. Die waarheid oor Christus wat verdedig is, is die waarheid dat Hy alleen die Seun van God is. Ander mense en gode kan nie met Hom vergelyk word nie. Hy alleen is ons weg na die Vader. Om hierdie rede het Origenes (Contra Celsum 8, 20) aangevoer dat Christene nie altare en tempels nodig het vir hulle diens aan God nie. Christus het alle 
offerpraktyke oorbodig gemaak. Arnobius (Adversus nationes 2, 65) het laastens bygevoeg dat slegs Christus die amp het om heil te bemiddel. Geen priester van enige heidense tempel kan heil bemiddel nie. Dít is die uitsluitlike voorreg van Jesus Christus.

\subsubsection{Absoluutheid op grond van die uniekheid van Christus}

Heidene het vinnig kennis geneem van Christus. Jode het die strategie gevolg deur daarop te wys dat daar vele Messiasverwagtinge binne die Jodendom bestaan. Jesus se aanspraak op Messiasskap is dus nie uniek nie. Die Grieke het die uniekheid van Christus probeer relativeer deur te wys op ander wonderdoeners soos Apollonius van Tyana en ander askete soos Plotinus. Die apologete se teenstrategie was om te wys op die onvergelykbare en unieke Wirkungsgeschichte van Christus, en op die feit dat niemand anders al hierdie verskillende elemente van buitengewoonheid in hulle persoon verenig het nie.

\subsubsection{Die Christendom as sintese van die ware godsdiens en ware filosofie}

In teenstelling tot die antieke mitologie, politieke teologie en misterie-kultusse het die apologete op die rasionaliteit en plousibiliteit van die Christelike godsdiens gewys. Hulle kritiseer die ander godsdienste se vlug van die logos (die soeke na wysheid) en skuiling in konvensies en tradisies. Vir hulle was die Christendom die "ware filosofie" - die sintese van ware godsdiens en ware filosofie. Hierdie sintese is moontlik aangesien die "waarheid" personale karakter vertoon. In Christus, sê Augustinus (De vera religione 5, 8) word denke (wysheid) en geloof verenig in 'n waarheid waarin almal behoort te deel.

\section{KONKLUSIE}

Die groeiende apostolêre bewussyn van die Hervormde Kerk, gaan kerk en wêreld ná aan mekaar bring. Ons wêreld is 'n gekompliseerde wêreld wat gekenmerk word deur talle teenstrydighede soos: die groei van die Christendom onder swartmense en hulle terugkeer na die tradisionele godsdienste; groeiende kerkvervreemding onder witmense en hulle grype na allerlei fundamentalistiese geloofsoortuigings. Dít alles maak ons bewus van één saak: Ons leef in 'n pluralistiese wêreld. Ons is terug by die Hellenistiese multi-godsdienstigheid. Die "verbalkanisering" van ons wêreld (Van de Beek) stel ons belydenis voor nuwe uitdagings. Ons het nie 'n keuse nie. Ons sal ons geloof moet verduidelik en verdedig (soos die meeste Christene alreeds in ander wêrelddele moet doen - kyk Hamilton 1975; Griffiths 1991). Ons sal moet regverdig en verhelder. Indien ons werklik ons apostolêre roeping wil 
gehoorsaam, sal ons apologie moet beoefen. Almal sal moet help. Elke vakgebied, elke predikant en elke lidmaat. Kom ons doen dit!

\section{Literatuurverwysings}

Adam, A 1931. Die Aufgabe der Apologetik. Leipzig: Dörffling \& Franke.

Bakhuizen van den Brink, J 1965. Handboek der kerkgeschiedenis, Eerste Deel: De Kerk tot Gregorius de Grote, 4e Druk. Den Haag: Bert Bakker.

Barnard, L 1978. s v Apologetik: Alte Kirche. TRE 370-411.

Barth, K Die Kirchliche Dogmatik, Band I, 1. [1932] 1964, Band II, 1 1958, Band IV, 3 1959. Zürich: EVZ.

Bavinck, J H 1954. Inleiding in de Zendingwetenschap. Kampen: Kok.

Bediako, K 1996. "How is Jesus Christ Lord?": Aspects of an Evangelical Christian apologetics in the context of African religious pluralism. Exchange 25(1), 2742.

Beißer, F 1969. Zur Grundlegung der Apologetik. KuD 15, 210-225.

Berdiajew, N 1930. Die Philosophie des Freien Geistes: Problematik und Apologie des Christentums. Deutsch von Reinhold von Walter. Tübingen: Mohr.

Bergjan, S 2001. How to speak about early Christian apologetic literature?: Comments on the recent debate. Studia Patristica XXXVI, 177-183.

Berkhof, H 1941. Geschiedenis der kerk. 2e Druk. Nijkerk: Callenbach.

Bolewski, H 1986. Der politische Kontext der Apologetik. KuD 32, 293-317.

Brunner, E 1929. Die andere Aufgabe der Theologie. ZdZ7, 255-276.

Brunner, E [1946] 1960. Dogmatik Band 1: Die christliche Lehre von Gott. 3.Aufl. Zürich: Zwingli.

Doerne, M 1950. Das unbewältigte Problem der Apologetik. ThLZ 75, 259-264.

Ebeling, G 1970. Erwägung zu einer evangelischen Fundamentaltheologie. ZThK 67, 479-524.

Fiedrowicz, M 2004. Christen und Heiden: Quellentexte zu ihrer Auseinandersetzung in der Antike. Darmstadt: WBG.

Fries, H 1985. Fundamentaltheologie. Graz: Verlag Styria.

Geerlings, W (Hrsg) 2002. Theologen der christlichen Antike. Darmstadt: WBG.

Griffiths, P J 1991. An apology for apologetics: A study in the logic of interreligious dialogue. New York: Maryknoll. (Faith meets faith.)

Haitjema, Th 1948. Dogmatiek als Apologie: 'lk geloof in den God van Jezus Christus. Haarlem: De Erven F Bohn N V.

Hamilton, K 1975. Apologetics and evangelization, in Let the earth hear his voice: International congress on world evangelization, 1194-1205. Lausanne, Switzerland. Official reference volume: Papers and responses, Douglas, J (ed). Minnesota, MN: World Wide Publications.

Harrison, P 1999. Prophecy, early modern apologetics and Hume's argument against miracles. Journal of the History of Ideas 60 (2), 241-256.

Hauschild, W-D 1995. Lehrbuch der Kirchen- und Dogmengeschichte. Band 1. Alte Kirche und Mittelalter. Gütersloh: Gütersloher Verlagshaus.

Heim, S [1995] 1997. Salvations: Truth and difference in religions. $2^{\text {nd }}$ Printing. New York: Maryknoll.

Helseth, P 2000. B B Warfield on the apologetic nature of Christian scholarship: An analysis of his solution to the problem of the relationship between Christianity and culture. WTJ 62, 89-111.

Hepp, V 1922. Gereformeerde Apologetiek. Kampen: Kok. 


\section{Die apologetiese taak van die kerk}

Jenssen, H 1971. Von der Apologetik zur Intellektuellen Diakonie. ThLZ 96, 801-810. Jongeneel, J 1999. $s v$ Apologetik: In der Mission. RGG ${ }^{4}$.

Logan, A 2001. Marcellus of Ancyra, defender of the faith against heretics and pagans. Studia Patristica XXXVII, 550-564.

McGrath, A [1992] 1996. Bridge-building: Effective Christian apologetics. Leicester: Inter-Varsity Press.

Meuleman, G 1973. Schleiermacher en de apologie van het Christelijk geloof, in Septuagesimo Anno: Theologische opstellen aangeboden aan Berkouwer, G C, 152-180. Bakker, J e a (red). Kampen: Kok.

Moreland, J 1996. Philosophical apologetics, the church, and contemporary culture. JETS 39 (1), 123-140.

Müller-Schwefe, H-R 1978. s v Apologetik: Praktisch-theologisch. TRE 424-429.

Neuenschwander, U 1975. Denker des Glaubens. Band 1. Gutersloh: Mohn. (GTB 81.)

Ott, H 1967. Hermeneutik, in Westermann, C (Hrsg), Theologie: VI x 12 Hauptbegriffe, 192-195. Stuttgart: Kreuz.

Ott, H 1994. Apologetik des Glaubens: Grundprobleme einer dialogischen Fundamentaltheologie. Darmstadt: WBG.

Pannenberg, W 1973. Wissenschaftstheorie und Theologie. Frankfurt: Suhrkamp.

Paulsen, H 1977. Das Kerygma Petri und die urchristliche Apologetik. ZK 88, 1-37.

Reid, J K S [1969] 1970. Christian Apologetics. Grand Rapids: Eerdmans.

Roscam Abbing, P J 1954a. Het gesprek met buitenkerkelijken. Deel I. s'Gravenhage: Boekencentrum.

Roscam Abbing, P J 1954b. Het gesprek met buitenkerkelijken. Deel II. Indirecte Apologie. s'Gravenhage: Boekencentrum.

Schleiermacher, F [1893] 1993. Kurze Darstellung des theologischen Studiums zum Behuf einleitender Vorlesungen. Kritische Ausgabe (Hrsg) v Scholtz, $\mathrm{H}$. Darmstadt: WBG (Bibliothek Klassischer Texte.)

Slenczka, R 1995. Apologetik als Auftrag der Kirche. KuD 41, 13-33.

Schrotenboer, P 1955. A new apologetics: An analysis and appraisal of the eristic theology of Emil Brunner. Kampen: Kok.

Skarsaune, O 1998. s v Apologetik: Kirchengeschichtlich: Alte Kirche. RGG.

Tertullian 1984. Apologeticum: Verteidigung des Christentums. 3.Aufl. Darmstadt: WBG.

Usarski, F 1998. s v Apologetik: Zum Begriff. RGG.

Van de Beek, A 2001. Ontmaskering: Christelijk geloof en cultuur. Zoetermeer: Meinema.

Van den Brink, G 1992. Lesslie Newbegin als postmodern apologeet. NTT 46, 302319.

Van der Horst, P 1998. s v Apologetik: Judentum. RGG.

Velema, W H 1996. De taak van de apologetiek in de hedendaagse theologie. Apeldoorn: Apeldoornse studies.

Veling, K 1995. Apologetisch motief. Barneveld: De Vuurbaak. (Kamper Bijdragen XXXIV.)

West, T 1979. Plato's apology of Socrates: An interpretation, with a new translation. London: Cornell University Press. 